\title{
Pathophysiological role of incomplete body adaptation and overactivation response reaction in diseases of internal organs
}

\author{
Z.M. Kit \\ Danylo Halytsky Lviv National Medical University, e-mail: zoryana.kit27@gmail.com
}

\begin{abstract}
The introduction of new approaches to determine the patient's condition and treatment efficacy is feasible only with adaptation responses, among which the incomplete adaptation and overactivation occupy an important place. The study of adaptation processes by adaptation index, relative content of blood lymphocytes, type of adaptation and state of its mechanisms was conducted in 1208 patients. Incomplete adaptation with flaccid inflammatory syndrome was detected in $15 \pm 4 \%$ of the set (3-30\%); with a high prevalence among patients with indices of digestive (5-30\%) and endocrine (3-28\%) systems. An increase in its frequency after treatment of liver diseases (from $34 \%$ to $45 \%$ ) may indicate an unfavorable prognosis. The frequency of detection of the overactivation reaction ranged from 0 to $12 \%$, and it also occurred more often among gastroenterological patients (about 4\%). Internal diseases had some peculiarities in these reactions: lower parameters of the function of external respiration were diagnosed in patients with bronchoconstriction; the adaptation index correlated with the main parameters of hemodynamics in cardiovascular patients; functional parameters were worse at a lower level of reactivity with changes in WBC differential in patients with chronic kidney disease. Reactions of incomplete adaptation and overactivation relate to distress and correlate with the course of inflammation, hemostasis and immune reactivity; determine severer course of the disease and functional changes in the remission stage.

Keywords: non-specific adaptive responses to stress; reactions adaptation; reactions overactivation.
\end{abstract}

\section{INTRODUCTION}

Modern internal medicine is characterized by constant increase in the morbidity of population and negative treatment results of many diseases that demand new methods of determining patient's condition as well as therapy efficacy that can be provided integrally and taking into consideration adaptation [1,2, $5,6,8]$. General non-specific adaptive stress reactions [8], training/orientation, calm and high arousal - increased activation (eustress), overactivation [1], inadequate adaptation [5] have been described; however, there role in pathophysiology [2], as well as clinical picture has been not defined yet. It especially concerns the reaction of overactivation and inadequate adaptation; their characteristic data are still fragmentary, although it is known that both of

(c) Z.M. Kit them have certain morphological changes that are proven by experiments. Typical feature of overactivation reaction is the increase in the number of lymphocytes in peripheral blood and rise of adaptation index [1]. Rats with overactivation reaction have exhausted thymus function, symptoms of tense work of immune and endocrine system and rather high weight of adrenals [4]. Determining feature of inadequate adaptation reaction is leukopenia in peripheral blood [5], and morphologically the reaction is characterized by low weight of adrenals, thymus degeneration and its low weight [4]. It is important that both of these distress types of adaptation reactions were determined only in rats receiving medications and were not determined at intact animals [4]. It proves the relevance and expedience of our research. 
The aim of the work was examine features of inflammation, immunity, hemostasis, endocrine and nerve system during formation of inadequate adaptation reaction and overactivation, the degree of their incidence and clinical peculiarities of the most frequent pathologies of internal organs.

\section{METHODS}

Characteristics of adaptation processes by the adaptation index (the ratio of segmented neutrophils to lymphocytes), relative lymphocyte level in peripheral blood [1], adaptation type (physiological, intermediate, pathophysiological) and the status of its mechanisms (exertion and overexertion) [5] were taken in 1208 patients with coronary heart disease, hypertension, bronchial asthma, chronic obstructive pulmonary disease, peptic ulcer, chronic gastritis and gastroduodenitis, chronic hepatitis and cirrhosis, chronic renal disease, diabetes, thyroiditis, goiter, their diagnoses are verified by the Protocol assistance and by Orders of Ministry of Health Care of Ukraine. Activity of inflammation syndrome was determined by the parameters of clinic blood count and level of C-reactive protein (CRP), seromucoid, sialic acids, general fibrinogen $(n=105)$. Homeostasis state was analyzed by phases (prothrombin, thrombin, fibrin formation) by the prothrombin index and time, prothrombin III, fibrinolytic activity, fibrinogen $B$, ethanol gelation test $(n=140)$, immunity system - by the divergence level of immunogram parameters from the norm [3] $(n=39)$, endocrine system - by aldosterone, cortisol, thyroxine, triiodothyronine, thyrotrophic hormone $(n=163)$. All the tests were conducted by standard laboratory biochemical, radioimmunoassay (aldosterone) and enzyme immunoassay methods in certified laboratories using standard reagents. Condition of the nervous system was estimated by psychoemotional state, anxiety, sympathetic and parasympathetic innervation using questionnaires (by Spielberger-Khanin,
Pukhlyk, Harkavy) $(n=79)$. Results were processed with analytical-statistical methods of variation statistics using program "Statistica for Windows 6.0" and by definition of Student criteria, basic absolute accuracy level was $<0.05$.

\section{RESULTS AND THEIR DISCUSSIONS}

It was established that reaction of inadequate adaptation and overactivation in patients with diseases of internal organs were less frequent than training and stress, however, their proportion was quite significant (Table 1).

Inadequate adaptation ranked third by its occurrence among all the examined patients after stress and training (on average 15+/$4 \%$ ). Inadequate adaptation was determined in different age groups and was not determined among healthy people. Most often it was determined in the patients with liver diseases (hepatitis, cirrhosis). The frequency of overactivation reaction was the lowest comparing to other types of reactions $(6 \pm 3 \%)$ and mostly determined among young people and old people. Most often it was found among patients with gastritis, gastroduodenitis and peptic ulcer.

The analysis of clinical course of internal diseases depending on formed adaptive reaction demonstrated that both reactions had certain clinical peculiarities. In general, the internal pathology was more complicated together with reaction of inadequate adaptation and overactivation despite the nosology. The length of hospitalisation was essentially longer. Fast indexes of expiratory function (FEV1, PEFexp, and FEV1/VC) were much lower compared to other reactions even during remission after hospital stay in patients with chronic obstructive bronchopulmonary pathology (asthma, chronic obstructive pulmonary disease). Moreover, despite the nosology the treatment of inflammation during these reactions was not coupled with any positive changes in peripheral blood with acutephase indexes (C-reactive protein, fibrinogen, seromucoid). Patients with coronary heart disease, hypertension disease with reaction of inadequate 
Table 1. Detection rate of adaptation reactions among 1208 patients with pathology of internal organs before treatment $(\%)$

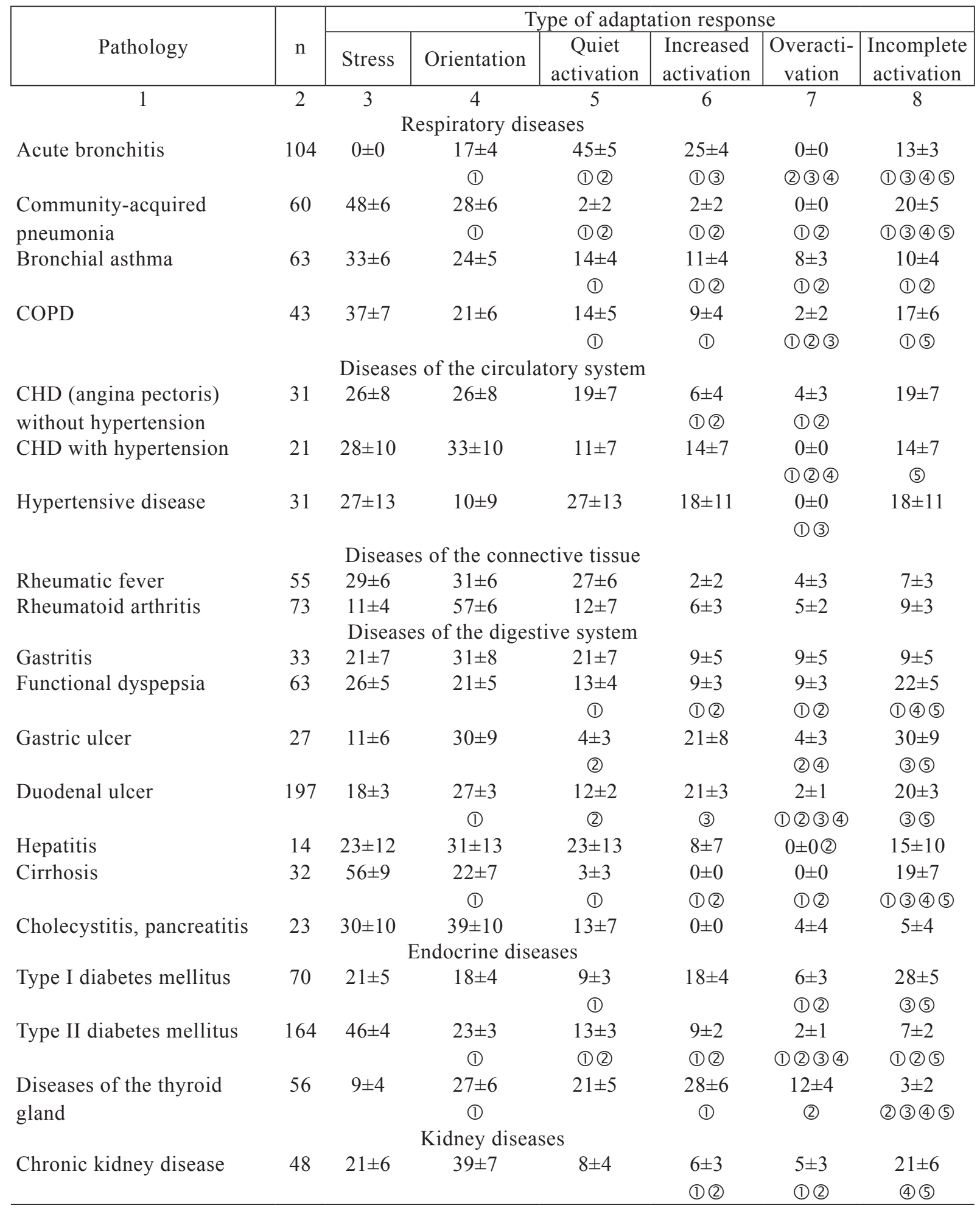

Note. The discrepancy is significant in comparison with stress (1), orientation (2), quiet activation (3), increased activation (4), overactivation (5). 
adaptation and overactivation had their adaptation index correlating with basic parameters of hemodynamics that can be the evidence of tense work of cardiovascular system and corresponds to literature data [6]. However, the reaction of inadequate adaptation was most frequently registered among patients with chronic hepatitis of both viral or toxic and autoimmune genesis (Table 1). After the period of treatment its incidence was even higher (from $34 \%$ to $45 \%$ ).

To our opinion it can be a predictively unfavorable symptom that is experimentally grounded [7]. Also functional indexes (glomerular filtration rate, blood creatinine) in patients with chronic kidney disease with inadequate adaptation and overactivation were essentially worse than in other types of adaptive reactions during hospital care and after it as well. Patients with diabetes mellitus had more frequent inadequate adaptation with the development of type I disease than with type II and mostly it was found among young patients. Overactivation reaction mostly accompanied thyroid diseases (Table 1). Such determined clinical peculiarities of internal pathology in the settings of reaction of inadequate adaptation and overactivation require thorough defining the influence of inadequate adaptation type onto basic pathophysiologic processes which cause the onset and development of basic internal diseases.

First of all, it was established that both types of adaptive reactions were on the low level of reactivity and it was shown by tense leukocyte formula (leukopenia, lymphocytosis, monocytopenia or monocytosis, eosinopenia or eosinophilia) (Table 2).

Table 2. Signs of stress of peripheral blood leukogram in patients with kidney diseases with different types of adaptation responses

\begin{tabular}{|c|c|c|c|c|c|}
\hline \multirow[b]{2}{*}{ Parameter, units } & \multicolumn{5}{|c|}{ Type of adaptation reaction } \\
\hline & Stress & Orientation & Activation & Overactivation & $\begin{array}{l}\text { Incomplete } \\
\text { activation }\end{array}$ \\
\hline The proportion of patients without & $0 \pm 0$ & $16 \pm 8$ & $0 \pm 0$ & $0 \pm 0$ & $0 \pm 0$ \\
\hline signs of stress, $\%$ & & (1) & (2) & (2) & (2) \\
\hline with 1 sign & $0 \pm 0$ & $32 \pm 11$ (1) & $15 \pm 13$ & $50 \pm 35$ & $20 \pm 13$ \\
\hline with 2 signs & $20 \pm 13$ & $32 \pm 11$ & $57 \pm 19$ & $0 \pm 0$ (2) (3) & $30 \pm 14$ (4) \\
\hline with 3 signs & $40 \pm 15$ & $16 \pm 8$ & $28 \pm 10$ & $0 \pm 0$ (1) (2) (3) & $40 \pm 15$ (4) \\
\hline with 4 signs & $40 \pm 15$ & $4 \pm 4$ (1) & $0 \pm 0$ (1) & $50 \pm 35$ & $10 \pm 9$ \\
\hline Average sign of stress, cu & $1.7 \pm 0.2$ & $0.9 \pm 0.1$ (1) & $1.0 \pm 0.1$ & $1.4 \pm 0.9$ & $1.0 \pm 0.2(1)$ \\
\hline Average stress by eosinophils, cu & $0.7 \pm 0.3$ & $0.2 \pm 0.2$ & $\begin{array}{c}0.1 \pm 0.1 \\
\text { (1) }\end{array}$ & $\begin{array}{c}0.5 \pm 0.5 \\
\text { (1) }\end{array}$ & $0.5 \pm 0.3$ \\
\hline Frequency of stress by eosinophils, $\%$ & $50 \pm 16$ & $\begin{array}{c}10 \pm 7 \\
\text { (1) }\end{array}$ & $14 \pm 13$ & $50 \pm 35$ & $30 \pm 14$ \\
\hline Average stress by band neutrophils, cu & $1.9 \pm 0.3$ & $0.9 \pm 0.3(1)$ & $0.6 \pm 0.2(1)$ & $0.5 \pm 0.5$ & $1.4 \pm 0.4$ \\
\hline Frequency of stress & $100 \pm 0$ & $47 \pm 11$ & $57 \pm 19$ & $50 \pm 35$ & $70 \pm 14$ \\
\hline by band neutrophils, $\%$ & & (1) & (1) & & (1) \\
\hline Average stress by monocytes, cu & $2.1 \pm 0.3$ & $\begin{array}{c}0.8 \pm 0.2 \\
\text { (1) }\end{array}$ & $1.4 \pm 0.6$ & $\begin{array}{c}3.0 \pm 1.0 \\
\text { (2) }\end{array}$ & $1.6 \pm 0.4$ \\
\hline Frequency of stress by monocytes, $\%$ & $90 \pm 9$ & $\begin{array}{c}47 \pm 11 \\
\text { (1) }\end{array}$ & $71 \pm 17$ & $100 \pm 0$ (2) & $80 \pm 13$ \\
\hline Average stress by leukocytes, cu & $2.1 \pm 0.4$ & $1.6 \pm 0.3$ & $2.0 \pm 0.6$ & $1.5 \pm 1.5$ & $\begin{array}{c}0.7 \pm 0.2 \\
\text { (1) (2) (3) }\end{array}$ \\
\hline Frequency of stress by leukocytes, $\%$ & $80 \pm 13$ & $58 \pm 11$ & $71 \pm 17$ & $50 \pm 35$ & $60 \pm 15$ \\
\hline
\end{tabular}

Note. The discrepancy is significant in comparison with stress (1), orientation (2), quiet activation (3), increased activation (4), overactivation(5). 
Perhaps, that is why reactions of inadequate adaptation and overactivation resembled each other by the basic characteristics of inflammation and by the basic parameters of immune system activity. Both reaction types were characterized with slow process of inflammation syndrome and the prevalence of destructive processes over the regenerative ones that can promote chronization of any pathology based on inflammation syndrome. Therefore in both reaction types the average C-reactive protein was essentially lower than during other reaction types (activation, training, stress). Sialic acid content, which is a marker of regeneration, appeared to be low $(0.20 \pm 0.02 \mathrm{~g} / 1)$, though that of seromucoids (marker of destruction) - high $(0.52 \pm 0.07 \mathrm{~g} / 1$, significantly more than under conditions of calm and increased activation) (fig. 1).

Determining configurations of immunograms during reactions of inadequate adaptation and overactivation by Koval (1994), held with a deviance level of every parameter demonstrated that both types correspond to "overactivation" type [3]. So the formula of dysimmunity in inadequate adaptation reaction includes maximum elements among all adaptive reaction types: Leucocytes2-, Lymphocytecom2-, T-lymphocytescom2-, B-lymphocytecom2-. Reaction of overactivation was characterized by availability of three elements in the formula, two of them however had the highest level of deviance - it was the increase of absolute amount of lymphocytes and general T-lymphocytes: Lymphocytescom3+, T-lymphocytescom3+, Leuco-T-index2-.

Both reactions were also accompanied by certain changes in hemostasis that maintains constancy of the body and is one of the main adaptive mechanisms. Therefore hypocoagulation prevailed in the first two phases of blood coagulation (prothrombinase and thrombin formation) in patients with the reaction of inadequate adaptation and reactivation. However, hypercoagulation was noted in the phase of fibrinogenesis that generally corresponded to the second phase of disseminated intravascular coagulation. It can indicate that any microtrauma with epithelium destruction can trigger the cascade irreversible systemic process of blood coagulation. To our opinion it becomes very important in case of acute cardiovascular attacks. However, this hypothesis requires some further studies.

According to the conventional description of stress-reaction by Selye [8], nervous and endocrine systems are essential ones in adaptive mechanisms; therefore we tested their state under conditions of such reactions. Our research showed that the studied characteristics of these systems vary considerably during the reactions of inadequate adaptation and overactivation from other adaptation reactions - stress, training and activation. So, the state of nervous system in patients with the reaction of inadequate

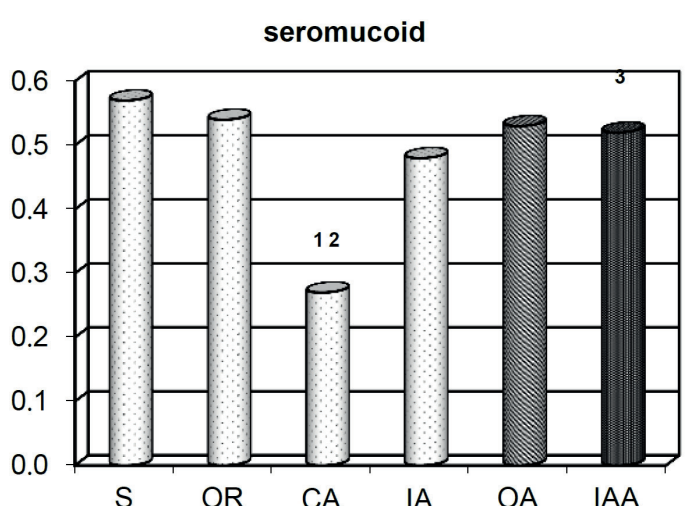

Figure 1. The levels of acute phase parameters of stress reaction $(\mathrm{S})$, orientation $(\mathrm{OR})$, calm activation (CA), increased activation (IA), overactivation (OA), inadequate adaptation (IA) 
adaptation was characterized by the high level of anxiety and anxiety of personality according to Spielberger-Khanin scale, high activity of sympathetic division of the nervous system (according to questionnaire by Puhlyk, 1998); the reaction of overactivation was marked with high level of aggressiveness and fatigue with minimal activity and working efficiency (according to questionnaire by Garkavi , 1998) and predominance of sympathetic innervation. Both reactions were accompanied with certain changes in hormonal state of patients regardless of nosology. It was defined that the reaction of inadequate adaptation was characterized by the change in the content of thyroid hormones, in particular, the amount of triiodothyronine was significantly lower than in orientation reactions and high arousal $(0.8 \pm 0.2 \mathrm{ng} / \mathrm{ml}$, to $1.4 \pm 0.1 \mathrm{ng} /$ $\mathrm{ml}, 1.4 \pm 0.2 \mathrm{ng} / \mathrm{ml}$, both $\mathrm{P}<0.05)$, and the level of thyroxin was minimal among all type of reactions (41 mg/ml). High weight of adrenals, which has been described in literature [4], in the experiment with overactivation reaction corresponded to determined growth of cortisol level to maximum value among all the reactions $(405 \mathrm{nM})$ regardless of nosology, which was accompanied by the reduction in the activity of thyroid gland: thyroxin level appeared to be significantly lower than in the reaction of orientation and balanced activation $(61.3 \pm 7.0 \mathrm{ng} / \mathrm{ml} \mathrm{vs.} 86.2 \pm 7.1 \mathrm{ng} / \mathrm{ml}$ and $88.3 \pm 7.5$ $\mathrm{ng} / \mathrm{ml}$, both $\mathrm{P}<0.05)$.

To our opinion both of these adaptive reactions of inadequate adaptation and overactivation develop in cases when body requirements do not correspond to its reaction: whether it is a poor response to powerful complex adaptive factor, or on the contrary - powerful response to poor stimulus. It is a noticeable fact that according to literature data [4] both types of reaction were noticed in animals that received medications, but not the intact ones. So these reactions can occur in patients as the response to drug administration. It should be considered before prescribing drugs especially for the elderly and seriously ill patients or with comorbid pathology.

\section{CONCLUSION}

1. General non-specific adaptive reactions of inadequate adaptation and overactivation belong to distress and are similar by the state of adaptive systems of the body and inflammation processes, hemostasis and immune reactivity.

2. Nervous system activity is manifested by high anxiety and aggressiveness, predominance of sympathetic innervation; endocrine system responds with changes of adrenal secretion and low level of thyroid hormones; immune system parameters indicate low or high activation of cellular component of immune system; hemostasis resembles syndrome of disseminated intravascular coagulation.

3. Both reactions cause severer course of disease with functional changes remaining even during remission. Formation of inadequate adaptation or overactivation reactions requires treatment revision for patients with the pathology of internal organs.

The authors of this study confirm that the research and publication of the results were not associated with any conflicts regarding commercial or financial relations, relations with organizations and/or individuals who may have been related to the study, and interrelations of co authors of the article.

\section{3. М. Кiт}

\section{ПАТОФІЗІОЛОГІЧНА РОЛЬ НЕПОВНОЦІН- НОЇ АДАПТАЦІЇ ОРГАНІЗМУ ТА РЕАКЦІї ПЕРЕАКТИВАЦІЇ ПРИ ХВОРОБАХ ВНУТРІШНІХ ОРГАНІВ}

Впровадження нових підходів до визначення стану хворого i ефективності терапії здійсненно тільки з урахуванням реакцій адаптації, серед яких важливе місце займають неповноцінна адаптація і переактивация. Дослідження адаптаційних процесів за індексом адаптації, відносному вмісті лімфоцитів крові, типу і стану механізмів адаптації проведено у 1208 хворих. Неповноцінна адаптація з в'ялим перебігом запального синдрому констатована в $15 \pm 4 \%$ вибірки (3-30\%); з високою поширеністю серед пацієнтів з показниками травної (5-30\%) і ендокринної (3-28\%) систем. Збільшення їі частоти після лікування хвороб печінки ( 334 до 45\%) може свідчити про несприятливий прогноз. Частота виявлення реакції переактивації коливалася від 0 
до $12 \%$, особливо серед пацієнтів з гастроентерологічними захворюваннями (близько 4\%). Внутрішні хвороби мали деякі особливості при цих реакціях: у хворих з бронхообструкцією діагностовані нижчі показники функції зовнішнього дихання; у пацієнтів кардіоваскулярного профілю індекс адаптації корелював 3 основними параметрами гемодинаміки; у хворих 3 хронічною хворобою нирок функціональні показники були гірші, на нижчому рівні реактивності зі змінами лейкоцитарної формули. Реакції неповноцінної адаптації і переактивації відносяться до дистресу і корелюють 3 перебігом процесів запалення, гемостазу і імунної реактивності; детермінують важчий перебіг хвороби і функціональні зміни в стадії ремісії. Ключові слова: неспецифічні адаптаційні реакції стресу; реакції неповноцінної адаптації; реакції переактивації.

Львівський національний медичний університет імені Данила Галицького; e-mail: zoryana.kit27@gmail.com

\section{3.М. Кит}

\section{ПАТОФИЗИОЛОГИЧЕСКАЯ РОЛЬ НЕПОЛ- НОЦЕННОЙ АДАПТАЦИИ ОРГАНИЗМА И РЕАКЦИИ ПЕРЕАКТИВАЦИИ ПРИ БОЛЕЗ- НЯХ ВНУТРЕННИХ ОРГАНОВ}

Внедрение новых подходов к определению состояния больного и эффективности терапии осуществимо только с учетом реакций адаптации, среди которых важное место занимают неполноценная адаптация и переактивация. Целью работы было исследовать их распространенность и особенности клиники болезней внутренних органов, характеристики воспаления, иммунитета, гемостаза, эндокринной и нервной систем в условиях формирования реакций неполноценной адаптации и переактивации. Исследование адаптационных процессов по индексу адаптации, относительному содержанию лимфоцитов крови, типу и состоянию механизмов адаптации проведено у 1208 больных. Неполноценная адаптация с вялым течением воспалительного синдрома констатирована в $15 \pm 4 \%$ выборки (3-30\%); с высокой распространенностью среди пациентов с поражениями пищеварительной (5-30\%) и эндокринной (3-28\%) систем. Увеличение ее частоты после лечения болезней печени (с 34 до 45\%) может свидетельствовать о неблагоприятном прогнозе. Частота выявления реакции переактивации колебалась от 0 до $12 \%$, особенно среди пациентов с гастроэнтерологическими заболеваниями (около 4\%). Внутренние болезни имели некоторые особенности при этих реакциях. Так, у больных с бронхообструкцией диагностированы более низкие показатели функции внешнего дыхания; у пациентов кардиоваскулярного профиля индекс адаптации коррелировал с основными параметрами гемодинамики; у больных с хронической болезнью почек были хуже функциональные показатели, на более низком уровне реактивности с изменениями лейкоцитарной формулы. Реакции неполноценной адаптации и переактивации относятся к дистрессу и коррелируют с течением процессов воспаления, гемостаза и иммунной реактивности; детерминируют более тяжелое течение болезни и функциональные изменения в стадии ремиссии.

Ключевые слова: неспецифические адаптационные реакции стресса; реакции неполноценной адаптации; реакции переактивации.

\section{REFERENCES}

1. Garkavi LH, Kvakina EB, Kuzmenko TS. Antistress reactions and activation therapy. Moskov: Imedis. 1998. [Russian].

2. Hzhehotskyy MR, Fedorenko YV. Condition of adaptive responses in the correction of the negative impact of stress factors of chemical nature. Fiziol Zh. 2006; 52 (5): 47-54. [Ukrainian].

3. Koval EA. Types of immunograms in patients with different clinical forms of ischemic heart disease and their individual prognostic value. Ukr J Cardiol. 1994; (5):56-60. [Ukrainian].

4. Panchyshyn MV. Radchenko OM. Condition of peripheral blood and organs of immune system in different adaptive responses in the experiment Fiziol Zh. 2002; 48 (3): 60-5. [Ukrainian].

5. Radchenko OM. Adaptive reactions in clinical picture of internal medicine Lviv: League-Press. 2004. [Ukrainian].

6. Radchenko O., Filipyuk A. General nonspecific adaptive reactions in cardiology. Lviv: League-Press 2014. [Ukrainian].

7. Bezpalko LY, Havryliuk OM, Zayachkivska OS, Hzhehotskyy MR. Role of prenatal metabolic stress in the processes of cell reorganization of liver (experimental study). Tavricheskiy Mediko-Biologicheskiy Vestnik. 2012; 15 (1):301-2. [Ukrainian].

8. Selye H. Present status of the stress concept . Clin Ther. 1977; 1(1): 3-15. 